\title{
Professionalism of State Civil Servants (ASN) in Public Services In Kecamatan Office Landasan Ulin, Banjarbaru City
}

\author{
Yuniarti Indah Sari, ${ }^{*}$ Asmu'I, Bachruddin Ali Akhmad
}

Master of Governmental Science, Faculty of Social and Political Science, Lambung Mangkurat University, Banjarmasin, Indonesia

\author{
DOI: $10.36348 /$ sjef.2021.v05i02.009 \\ | Received: 09.02.2021 | Accepted: 23.02.2021 | Published: 26.02.2021 \\ *Corresponding author: Yuniarti Indah Sari
}

\section{Abstract}

The state civil apparatus is expected to have integrity, be professional, neutral, and free from political intervention, free from corruption, collusion, and nepotism (clean government), and be able to realize good governance in providing public services for the community. However, problems were still found regarding the organizational structure, less accommodating work mechanisms, and an increase in service needs that were not comparable to the skills and skills of the apparatus. This study aims to analyze the quality of administrative services and services. This type of research is qualitative. Data collection was carried out by interview and field observation. Data were analyzed descriptively. Apparatus at the Landasan Ulin District Office can be said to be professional when viewed from the aspect of attitude, namely creativity, innovation, and responsiveness.

Keywords: Professional; State Civil Apparatus; Public service.

Copyright (C) 2021 The Author(s): This is an open-access article distributed under the terms of the Creative Commons Attribution 4.0 International License (CC BY-NC 4.0) which permits unrestricted use, distribution, and reproduction in any medium for non-commercial use provided the original author and source are credited.

\section{INTRODUCTION}

Law Number 23 of 2014 concerning Regional Government, the renewal of Law Number 32 of 2004 states that the implementation of regional government is directed at accelerating the realization of community welfare through improving services, empowerment, and community participation, by taking into account the principles of democracy, equity, justice, and uniqueness an area. The application of this Law is expected to build a state civil apparatus that has integrity, is professional, neutral, and is free from political intervention, is free from corruption, collusion, and nepotism practices (clean government), and can realize good governance in providing services, public for society.

The government is required to be able to provide services to meet the needs of a society that is growing and changing dynamically. Thus the role and work of the government must change following the demands and dynamics of society. Public government services that involve all state civil servants are increasingly felt by increasing public awareness of the right to good and quality services.

Problems that occur in organizational life are still frequently found, among others, concerning the organizational structure (structure problems) which are linked to the working mechanism of the top-down system which is less accommodating to the aspirations of subordinates and the people served, often causing inequality between service operators, service needs and bureaucratic service products. Sometimes it also happens when people's need for public services increases without the expertise and skills of the apparatus to form a good service work mechanism. There are still frequently encountered apparatus services with convoluted (bureaucratic) procedures, lack of certainty, lack of transparency, lag, and sometimes additional fees outside the official fees. As a result that can be seen today, many people who use government services are often faced with a lot of uncertainty when they are dealing with bureaucratic apparatus [1].

The unprofessionalism of the Indonesian public bureaucracy can be seen from the many findings of experts and personal experiences of the community in the field regarding public services organized by the bureaucracy. The slow bureaucracy in responding to public aspirations, overly procedural services (red tape), and the lack of innovation in the bureaucracy are just a few examples among the many irregularities in the world of Indonesian public bureaucracy. Also, the 
Yuniarti Indah Sari et al., Saudi J Econ Fin, Feb, 2021; 5(2): 85-89

professionalism of the apparatus often collides with the absence of a conducive climate in the world of bureaucracy to respond to the aspirations of the community and the absence of the willingness of leaders to empower subordinates. According to Isa [2], the effectiveness of District Organizations as an effort to improve services to the community is already a demand where the sub-district organization is the spearhead of service which is a reflection of the services provided by the regional government in the implementation of regional autonomy.

In the Landasan Ulin District Office, Banjarbaru City, the total number of personnel is 34 people, with 2 undergraduate (S2) educational backgrounds, 19 undergraduate (S1) educational backgrounds, as many as 19 Diploma III (DIII) educational backgrounds 4 people, 8 people with high school educational background and 1 person with SD education background. Based on these data, it can be seen that the state civil servants in the Landasan Ulin sub-district with an undergraduate education background reach $55.9 \%$, while the rest have S2, DIII, SLTA, and SD education. This fact is expected that they will be able to analyze the dynamics of the work environment and the external environment such as changing community needs and technological advances. This is a challenge in itself for Landasan Ulin District in particular, and Banjarbaru City in general, to build a professional apparatus to carry out its function as one of the agencies providing public services.

Landasan Ulin sub-district is one of 5 (five) sub-districts in Banjarbaru City that has received the delegation of authority to carry out integrated administrative services (PATEN) which, with this delegation of authority, of course, the burden of duties and responsibilities is getting bigger. For maximum service, Landasan Ulin District apparatus are required to work professionally following standard operating procedures (SOPs) and applicable regulations. However, according to the observations of researchers, there are still some deficiencies related to the professionalism of the state civil apparatus (SCA) in the Landasan Ulin District Office, such as there is still an administration that is too bureaucratic and there are still officers who are not polite in providing services to the community.

In the framework of implementing a good governance system (good governance), the State Civil Apparatus is required to be able to become professionals in carrying out their duties. To be able to carry out these tasks, a State Civil Apparatus is required to carry out their duties in a professional manner and are responsible for carrying out government and development tasks. Concerning the things mentioned above, the authors are interested in researching: "Professionalism of the State Civil Apparatus (SCA) in Public Services at the Landasan Ulin District Office, Banjarbaru City"[3].

\section{METHOD}

This research uses a qualitative approach. The researcher will go directly to the field to examine the object of his study and conduct direct interaction with the community which aims to obtain more in-depth information about the professionalism of the state civil apparatus (SCA) in public services at the Office of the Head of Landasan Ulin, Banjarbaru City which affects the Professionalism of the State Civil Apparatus (SCA) in Public Services at the Head Office of Landasan Ulin, Banjarbaru City. Data obtained from direct interviews and field observations. Data analysis was carried out descriptively.

\section{RESULTS AND DISCUSSION}

The professionalism of the state civil apparatus is a form of the ability of an apparatus/employee to carry out their duties and functions effectively and to be able to respond to the existing dynamics in the surrounding environment, including the development of community needs and demands by creating innovations to achieve goals in the implementation of development and services professional public.

Apparatus whose professionalism is measured from the aspect of innovation and responsiveness is an ability possessed by the apparatus to provide services to the community, especially the ability to read and anticipate various changes so that they can quickly respond to the needs and desires of the community, besides being able to innovate as an effort to find new ways and methods of work that are more effective and efficient to produce several outputs following the goals of the organization and the desires of society.

The Landasan Ulin Sub-District Office of Banjarbaru City was originally formed following the Regional Regulation of the City of Banjarbaru Number 22 of 2001 concerning the Establishment of the Organization and Work Procedures of the Regional Apparatus and the Civil Service Police Unit of the City of Banjarbaru so that by referring to the intended Regional Regulation, the Landasan Ulin District of Banjarbaru City has become a government apparatus. Banjarbaru City, which has the task of carrying out administrative functions in the City of Banjarbaru.

Juridically, the formation of Landasan Ulin District as one of the areas in Banjarbaru City coincided with the formation of the City of Banjarbaru as an autonomous region based on Law Number 9 of 1999 concerning the Establishment of a Banjarbaru Level II Regional Municipality (State Gazette of 1999 Number 43, Supplement to the State Gazette Number 3822)[4].

The government's duty is also the right of the community, one of which is the implementation of community services. Landasan Ulin sub-district which has the main task of carrying out the authority given by 
the Mayor of Banjarbaru in carrying out governance, development and guidance to the community in the subdistrict also carries out other government tasks that are not included in the implementation of regional apparatus duties and/or other agencies. In the relationship between the government and the community, service sometimes becomes an indicator to assess whether a government can be said to be professional/good or not.

ASN professionalism is assessed from several aspects, in this study includes two, namely innovation in administrative services and innovation in service delivery.

\section{Innovation in Administrative Services}

Innovation is a form of embodiment of the quality of the bureaucracy by prioritizing the creativity of the bureaucratic group to create a new work model that aims to facilitate the implementation of tasks and community services. From 2016 until now, innovations to create new working models are increasingly being launched in Banjarbaru City, as well as in the Landasan Ulin District Office.

Innovation in the form of embodiment of new work models or the use of technological advances to increase the self-expertise of employees. The Banjarbaru City Government itself has provided internet facilities in each SKPD, even provides free wifi in certain places, including in the Landasan Ulin District Office itself, several internet networks can be accessed free of charge by the public such as @free.banjarbaru and @wifi.banjarbaru. Technological advances that are increasingly growing are a serious concern for the Landasan Ulin District apparatus, the implementation of work is not only limited to their knowledge and abilities. The desire to develop personal abilities has been considered a priority, as expressed by the staff of the General and Civil Service section, Riky said that:

"Not only computer-savvy people are given jobs, those who can't be computers are also given light work, so those who are clueless are required to want to learn computers, and the General and Civil Service Sub-Division itself has innovated by making personnel data applications, namely the Rank Order List. (DUK), so that our employee rank data is helped" (interview on 12 September 2019).

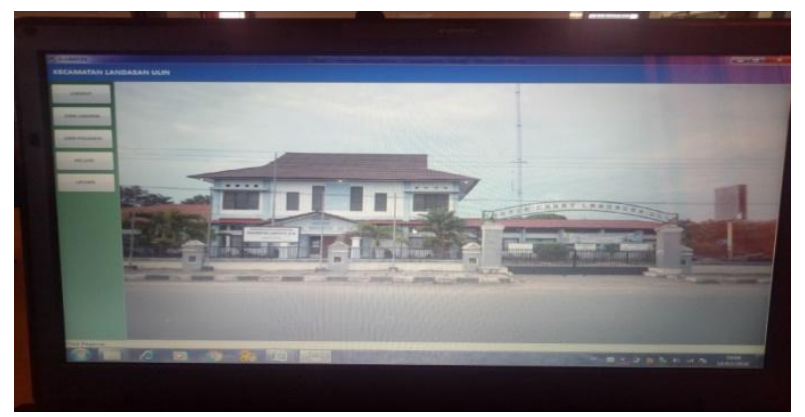

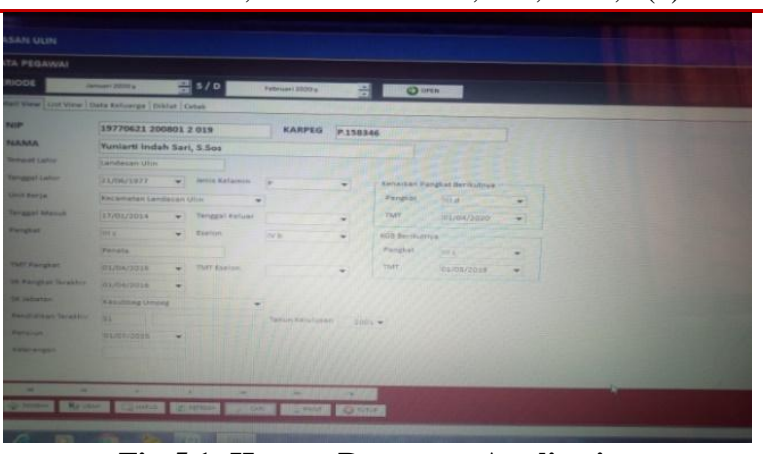

Fig-5.1: Human Resources Application

The same thing was expressed by Mr. Asep Alamsyah, from the Peace and Order Section:

"I am an old person who wants to retire, usually just typing smoothly using old school typewriters, but now it's not used anymore. So if there is a letter that is urgent to reply to immediately I have to draft it first, then ask a friend to type it using a computer, if for letters for archives or data in the office I can also type computer but it's slow, the important thing is we those who are old have made efforts to learn, don't be lazy, don't want to lose to the young ones." (interview, 13 September 2019).

The innovation that has been considered a frightening specter can be broken by the many innovations and changes that have occurred in Landasan Ulin District. As stated by the Head of Subdivision of Planning and Finance, Landasan Ulin District, Asmarabia:

"The proof is that we can innovate and get the best results. I have proven this myself by making innovations in terms of verification of financial accountability, namely the VerJaKa application (Verification of Financial Accountability). This application is used to verify financial accountability if it does not use multiple SPJs and reduces the pile of files, just one file which is then scanned using this application. And this is proven by obtaining the best predicate in Level IV Leadership Education and Training conducted by the South Kalimantan Provincial Education and Training Agency." (interview on 18 September 2019).

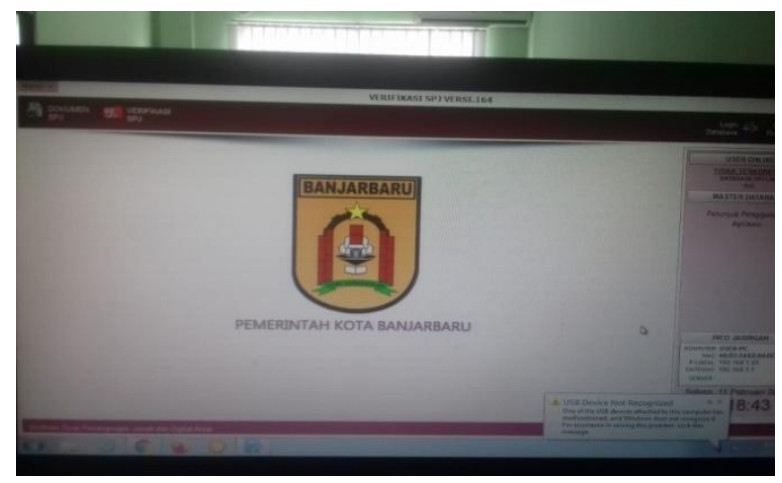

Fig-5.2: VerJaka Application 
Yuniarti Indah Sari et al., Saudi J Econ Fin, Feb, 2021; 5(2): 85-89

Apart from several innovations related to the performance of the apparatus, there are still innovations that are directly related to providing services to the community, such as innovations about Dasa Wisma data through the SI-DWI Application (Dasa Wisma Information System Application), which with this application the community become more recorded and easily known about the activities of the Dasa Wisma, such as activities aimed at improving family health and activities that lead to improving the family economy. Community data becomes inventoried with this application so that officials at the Landasan Ulin District Office, especially in the Social Welfare Section, are assisted in providing services to the community in distributing social assistance, educational assistance, and other assistance. As stated by Mrs. Sugiaty:

"We, as residents, are very grateful for the services provided by the Landasan Ulin District, because when we apply for a certificate for a child scholarship, it can be processed quickly, because the data is already in the office, he said. the data is obtained from each Kelurahan through the Head of the RT in each Kelurahan." (interview on September 20, 2019).

Based on some of these statements, it can be seen that the apparatus innovation in the bureaucratic environment of Landasan Ulin District in the form of administrative services has been professional and has undergone many changes that support the running of government and development because there are already several ideas and ideas to facilitate the implementation of tasks so that the work in providing community services to be better.

\section{Innovation in Services}

With the existence of various technological advances which are an increase in the discovery of human knowledge from time to time, it is starting to think about how services in the public bureaucracy can fulfill what the community wants as service users. At the Landasan Ulin District Office itself, innovation in services can be seen from the presence of officers appointed to help people who are suffering from the death of their family members in the management of death compensation assistance provided by the Banjarbaru City Government to the community.

As stated by Rogayah, a resident of East Landasan Ulin Village who stated that:

"Alhamdulillah, our family and we are very much helped by the services provided by the District Office, because when we were hit by an accident when our parents left us, we were helped for the matter of death compensation, we just accept it, we pay the most for stamp duty." (interview on 24 September 2019).

Mrs. Esti Wahyuni, Head of RT.03 Kelurahan Guntung Payung revealed that:
"As the Head of the RT, I am very grateful to the employees of the Landasan Ulin District Office who have helped our residents who were hit by the death of their family, because they have been helped to take care of their death benefits until they are over, so the family doesn't have to bother taking care of it." September 25, 2019).

From several statements obtained in this study, it can be seen that innovation in terms of services that have been carried out by the State Civil Apparatus (SCA) at the Landasan Ulin District Office is professional because the community as service recipients is very satisfied with the services provided.

\section{Responsiveness in Administrative Services}

Responsiveness is one indicator that can be used to get a picture of the professionalism of the state civil apparatus. Responsiveness is the ability of the apparatus to be able to read and understand the various needs of the organization, both those originating from within (internal) the organization itself and those from the community. Thus, this states that a state civil servant has good responsiveness if he has a level of concern and sensitivity to various dynamics that often occur in society. This sensitivity and concern are very important, considering that in the era of globalization and the era of very sophisticated technology, change is also very fast and complex. This inevitably will have an impact (influence) on an organization and society as service users/services from the Government. Therefore we need an effort to anticipate new developments and new knowledge.

The ability to respond to this gives the apparatus the possibility to deeply identify the needs of the organization and the needs and wants and aspirations of the community. Efforts made by Landasan Ulin District to respond to public aspirations and community progress include organizing the following activities:

\section{a. Provide a suggestion box}

Another method used by Landasan Ulin District in accommodating public aspirations is by providing a suggestion box that is placed in the service room. In the interview I conducted with the Head of Government Section, Mrs. Norjanah stated that:

"This suggestion box has been provided since 2009, intended to accommodate the aspirations and complaints of the public who may be reluctant or embarrassed to convey it directly to the sub-district officials and every week the suggestion box is opened for a response" (interview on 12 September 2019).

\section{b. Hold meetings with the Heads of the Village, Kasi, Kasubag, and staff in the Landasan Ulin District}

The meeting with the Lurah, Head of Section, Head of Subdivision, and Staff in the Landasan Ulin 
Yuniarti Indah Sari et al., Saudi J Econ Fin, Feb, 2021; 5(2): 85-89

District area is intended to get suggestions, opinions, criticism as well as to be able to exchange opinions, in addition to conveying government policies that must be conveyed to the public.

Based on the author's interview with the Head of Landasan Ulin sub-district, Mr. Subhan who stated that:

"With a meeting or meeting with the Heads of the Village, Head of Section and Head of Subdivision in the Landasan Ulin District Government, we can share complaints and input from the public regarding services both in the Kelurahan and in the District" (interview on 17 September 2019).

\section{c. Hold a dialogue in the form of RT/RW Forum meetings for the Landasan Ulin District}

Likewise, the holding of dialogues/meetings with RT / RW in the Landasan Ulin District, as conveyed by Mr. Saimbran, Head of the RT / RW Forum, Landasan Ulin District:

"Through RT / RW forum meetings in the Kelurahan and Kecamatan, there are many suggestions and input from the community that can be conveyed, most of which are regarding government facilities and accelerated development, cutting service lines that the community considers too long and convoluted as well as community requests. to be given free services for the poor "(interview on 15 September 2019).

\section{Responsiveness in Services}

The responsiveness that has been carried out by the State Civil Apparatus (SCA) at the Landasan Ulin District Office can also be seen from the aspect of its services. As the statement from Mrs. Ellyanti, a resident of Guntung Payung Village stated that:

"I was greatly helped by the service in Landasan Ulin District, because our complaints were quickly responded to, like what happened in our RT yesterday, poor people were suffering from tumors and desperately need medical assistance to the hospital, thank God from the District side immediately came to visit residents and provide assistance by bringing to the hospital and giving a certificate of inability to the hospital. " (interview on September 20, 2019).

Another statement, such as that expressed by Mr. Mardianto, a resident of Landasan Ulin Timur Village, stated that:
"For services in other fields, we, as residents of the Landasan District community, are also very grateful for the prompt response from the District, such as the provision of a free Ambulance that can be used by the residents of Landasan Ulin District, so residents who are affected by a disaster do not need to go far. looking for an ambulance, just contact the Landasan Ulin District Office to borrow it. " (interview on September 20, 2019).

From several statements about responsiveness in these services, it can be said that the services provided are professional. Responsiveness in services refers to the initiative or awareness of the authorities to provide better services to the people who need them.

\section{CONCLUSION}

Apparatus at the District Office of Landasan Ulin can be said to be professional when viewed from the aspect of attitude, namely creativity, innovation, and responsiveness, namely the Professionalism of the State Civil Apparatus (ASN) from the aspect of attitude (innovation and responsiveness). From the aspect of innovation, the state civil apparatus (ASN) at the Landasan Ulin District Office is professional, this can be seen from the existence of several innovations that have been made at the Landasan Ulin District Office, and the active role of the leadership in providing support to subordinates to submit new ideas or innovations as well as opinions. The state civil apparatus at the Landasan Ulin District Office, when viewed from the aspect of responsiveness, is also professional, seen from the apparatus who are trying to find new information in the implementation of work, the existing work relationship is quite good, the level of catching power is good and the work plan preparation is good. Under the applicable standard service procedures.

\section{REFERENCE}

1. Dwiyanto, A., dan Kusumasari, B. (2001). Kinerja Pelayanan Publik, Center for Population and Policy Studies, Yogyakarta.

2. Isa, R., (2009). Efektivitas Organisasi Kecamatan dalam Pelayanan Publik setelah menjadi perangkat Daerah. Jurnal Inovasi, 6(04).

3. Yustisia, T.V. (2015). Undang-Undang No 23 Tahun 2014 tentang Pemerintahan Daerah dan Perubahannya. VisiMedia.

4. Indonesia, R. (2007). Undang-Undang Nomor 32 Tahun 2004 tentang Pemerintahan Daerah. Pustaka Yustisia. 